\title{
HUBUNGAN ANTARA KOMPETENSI MANAJERIAL KEPALA SEKOLAH DAN IKLIM SEKOLAH DENGAN KINERJA GURU
}

\author{
Daniel \\ Manahan P. Tampubolon \\ manahan_tb@yahoo.com \\ Hotmaulina Sihotang \\ hotmaulina.sihotang@uki.ac.id
}

\begin{abstract}
Abstrak
Penelitian ini bertujuan untuk mengetahui hubungan antara kompetensi manajerial kepala sekolah dan iklim sekolah dengan kinerja guru. Penelitian ini dilaksanakan di delapan sekolah dasar swasta kecamatan Penjaringan Jakarta Utara. Metode yang digunakan adalah survei dengan teknik korelasional. Sampel yang digunakan di dalam penelitian ini berjumlah 108 guru. Data diperoleh melalui kuisioner. Validitas butir instrumen menggunakan rumus korelasi Product Moment, sedangkan uji reliabilitas dengan rumus Alpha Cronbach. Persyaratan analisis data dilakukan dengan uji normalitas dan linieritas. Analisis data menggunakan korelasi dan regresi. Hasil pertama, terdapat hubungan yang positif dan signifikan antara kompetensi manajerial kepala sekolah (X1) dengan kinerja guru (Y). Diperoleh koefisien korelasi sebesar 0,687 dan persamaan regresi $\hat{Y}=32,144+$ $0,617 \mathrm{X}_{1}$. Kedua, terdapat hubungan yang positif dan signifikan antara iklim sekolah (X2) dengan kinerja guru $(\mathrm{Y})$ serta diperoleh koefisien korelasi sebesar 0,463 berarti memiliki korelasi positif dan cukup kuat dan persamaan regresi $\hat{Y}=44.960+0,487 \mathrm{X}_{2}$. Ketiga, terdapat hubungan yang positif dan signifikan antara kompetensi manajerial kepala sekolah (X1) dan iklim sekolah (X2) secara simultan dengan kinerja guru (Y). Diperoleh koefisien korelasi ganda (ry12) sebesar 0,703 yang berarti korelasi positif dan kuat dan persamaan regresi $\hat{Y}=25,138+0,544 X_{1}+0,176 X_{2}$.
\end{abstract}

Kata Kunci: Kinerja Guru, Kompetensi Manajerial Kepala Sekolah, Iklim Sekolah 


\section{A. PENDAHULUAN}

Pendidikan merupakan kebutuhan dan tuntutan masyarakat yang diharapkan mampu mewujudkan manusia Indonesia yang berkualitas. Untuk memenuhi kebutuhan serta tuntutan tersebut, maka peran sekolah merupakan organisasi terpenting untuk mewujudkan penyelenggaraan pendidikan yang berkualitas. Seperti yang tertuang di dalam UU RI No. 20 tahun 2003 pasal 1 ayat 10 mengatakan bahwa sekolah adalah penyelenggara pendidikan formal yang terstruktur dan berjenjang yang terdiri atas pendidikan dasar, pendidikan menengah, dan pendidikan tinggi, sehingga dapat dikatakan bahwa sekolah adalah organisasi yang berwenang untuk menyelenggarakan proses belajar mengajar untuk mewujudkan tujuan pendidikan nasional. Usaha dalam menghasilkan tujuan tersebut tentu tidak lepas dari peranan guru di lembaga pendidikan.

Guru sebagai ujung tombak pelaksanaan pembelajaran harus melaksanakan tanggung jawabnya sebagai pengajar dan pendidik di sekolah English (2006: 1012). Hal ini juga senada dengan pendapat Tirtarahardja dan Sulo (2012: 54) yang mengatakan bahwa pihak yang paling berperan terhadap dunia pendidikan di sekolah adalah guru. Ungkapan ini menegaskan bahwa guru merupakan jantung pendidikan, karena tanpa keterlibatan aktif para guru, kebijakan secanggih apapun akan berakhir sia-sia. Berdasarkan hal tersebut, maka hal menarik untuk diteliti pada penyelengaraan pendidikan di level mikro yaitu tentang kinerja guru. Selain menarik hal ini juga merupakan hal yang cukup krusial karena kualitas kinerja guru di Indonesia berada di peringkat 5 di antara 10 negara ASEAN.

Sesungguhnya pemerintah sudah memberikan perhatian yang besar terhadap pendidikan khususnya kesejahteraan guru, seperti pemberian dana hibah, sertifikasi guru, pelatihan guru dan lain-lain. Melihat kebijakan oleh pemerintah maka dapat diasumsikan bahwa kinerja guru tentu akan meningkat. Namun usaha tersebut tidak serta merta sesuai dengan harapan, seperti yang di tulis didalam Koran Jakarta (http://www.koranjakarta.com/kinerja-guru-belum-efektif/), diakses 27 Februari 2018. Dalam berita tersebut, Muhadjir Effendi (Menteri Pendidikan) mengatakan kompetensi dan kualifikasi belum sepenuhnya optimal dalam menghadapi revolusi industri 4.0 dan ia juga menyimpulkan kinerja guru belum sepenuhnya efektif ditambah distribusi guru yang belum merata.

Secara umum banyak variabel-variabel yang dapat memengaruhi kinerja guru. Dari hasil informasi yang diperoleh menunjukkan bahwa rendahnya hasil kerja pada sekolah dasar swasta kecamatan Penjaringan Jakarta Utara disebabkan oleh beberapa faktor diantaranya adalah jumlah guru baik dari segi kuantitas ataupun kualitas masih kurang sehingga guru harus mengajar yang tidak sesuai dengan latar belakang pendidikanya. Selain itu juga dipengaruhi kompetensi kepemimpinan dan iklim organisasi.

Tampubolon (2012: 160) menyatakan faktor yang memengaruhi kinerja seseorang adalah hubungan antar karyawan dan mutu kepemimpinan. Guru 
akan melaksanakan tugas serta tanggung jawabnya sebagai seorang pendidik dengan baik, apabila kepala sekolah mampu dalam mengelola seluruh sumber daya serta komponen di dalamnya dan sebaliknya jika kepala sekolah tidak mampu untuk mengelola, maka kinerja guru tidak akan sesuai dengan apa yang diharapkan. Dalam hal ini kemapuan seorang kepala sekolah dalam mengelola sumber daya untuk mencapai visi dan misi di sebut kompetensi manajerial kepala sekolah. Selain itu, iklim sekolah yang tidak sehat juga menciptakan suasana organisasi yang tidak nyaman dan akan mengganggu proses kegiatan aktivitas di sekolah yang pada akhirnya memengaruhi kualitas kinerja (Sihotang, 2017).

Berdasarkan hal di atas, maka kompetensi manajerial kepala sekolah dan iklim sekolah menjadi perhatian yang penting untuk diperhatikan demi menjaga kualitas kinerja guru di sekolah dasar swasta wilayah Kecamatan Penjaringan Jakarta Utara.

Kompetensi manajerial kepala sekolah adalah seperangkat keterampilan teknis dalam melaksanakan tugas sebagai manajer sekolah untuk mendayagunakan segala sumber yang tersedia untuk mencapai tujuan sekolah secara efektif dan efisien (Topping, 2002: 17). Sehubungan dengan hal tersebut, Winterton et al. (2002) dan Yukl (2013) menyampaikan bahwa kemampuan manajerial itu meliputi technical skill, human skill dan conceptual skill. Technical skills adalah kemampuan untuk menggunakan pengetahuan, metode-metode, prosedur, teknik dan akal yang diperlukan untuk melaksanakan tugas spesifik yang diperoleh lewat pengalaman, pendidikan, dan pelatihan. Interpersonal skills adalah kemampuan mengembangkan hubungan yang harmonis dengan semua anggota lembaga atau organisasi. Conceptual skills adalah keterampilan konseptual, yaitu keterampilan yang harus dimiliki oleh kepala sekolah untuk menentukan strategi, merencanakan, merumuskan kebijakan, serta memutuskan suatu yang terjadi dalam organisasi termasuk sekolah sebagai lembaga pendidikan.

Selain dari kompetensi manajerial kepala sekolah faktor yang juga memengaruhi kinerja guru adalah iklim sekolah. Iklim sekolah pada prinsipnya merupakan suasana bekerja, bergaul, dan belajar dalam organisasi pendidikan (Pidarta, 2013). Ehrhart (2014: 32) menjelaskan bahwa iklim organisasi merupakan refleksi kondisi fisik dan psikologi di dalam organisasi yang memengaruhi perilaku individu di dalamnya. Iklim sekolah yang sehat dapat menciptakan suasana yang nyaman bagi guru ketika berada di sekolah, sehingga akan memotivasi guru untuk meningkatkan kualitas mengajarnya dan menghasilkan mutu pendidikan yang baik. Iklim organisasi yang kondusif tidak hanya dibutuhkan oleh stakeholders, guru pun mendambakannya, karena bisa menumbuhkan semangat guru. Hal ini mengindikasikan bahwa dengan iklim sekolah yang sehat akan memiliki produktivitas kinerja yang tinggi.

\section{B. KAJIAN TEORI}

\section{Kinerja Guru}

Kinerja dikenal dalam bahasa Inggris dengan sebutan work performance atau job performance. Dessler (2014:97) menyatakan kinerja adalah hal yang hampir sama dengan prestasi kerja karena keduanya dijadikan indikator untuk mengukur standar kerja yang ditetapkan sebelumnya. 
Kinerja juga merupakan unjuk kemampuan yang berlandaskan pengetahuan, sikap, ketrampilan serta motivasi dalam menciptakan sesuatu (Sihotang, 2017: 13). Secara khusus kinerja guru merupakan hasil kerja nyata secara kualitas dan kuantitas yang dicapai oleh seorang guru dan tugas utama guru dalam melaksanakan pekerjaannya yaitu, bagaimana menjalankan proses kegiatan belajar mengajar di kelas dengan baik (Hayes et al., 2006).

Kinerja guru kini menjadi hal yang krusial sebagai feedback sekaligus sebagai acuan bagi perbaikan kinerja selanjutnya. Pada sektor pendidikan tentunya kinerja guru perlu untuk ditingkatkan, mengingat sekarang sudah menginjak revolusi industri 4.0 artinya persaingan kompetensi semakin meningkat. Oleh karena itu sebagai tenaga pendidik yang terlibat langsung dalam proses pengajaran di kelas harus rajin mengasah diri untuk menjadi lebih baik lagi melalui evaluasi kinerja guru.

Georgia Departemen of Education telah mengembangkan teacher performance assessment instrument yang kemudian dimodifikasi oleh Depdiknas (2008) Tentang Peningkatan Mutu Pendidik dan Tenaga Kependidikan menjadi alat penilaian kemampuan guru (APKG). Alat penilaian kemampuan guru meliputi: Rencana pembelajaran (teaching plans and materials) atau biasanya disebut rencana pelaksanaan pembelajaran, prosedur pembelajaran (classroom procedure) dan hubungan antar pribadi (interpersonal skill). Kemudian, Permendiknas no. 35 tahun 2010 juga menuliskan tahapan-tahapan penilaian kinerja guru yang dikelompokkan menjadi enam bagian utama, yaitu merencanakan pembelajaran, melaksanakan pembelajaran dan melakukan evaluasi atau penilaian hasil pembelajaran, membimbing kegiatan ekstrakurikuler dan membimbing guru pemula dan pengembangan diri. Torrington et al. (2004: 17) dan Swainston (2008) juga memaparkan indikator-indikator penilaian terhadap profesionalisme guru yang dilihat berdasarkan persiapan dan perencanaan pembelajaran, pelaksanaan pembelajaran, penilaian, kehadiran, pendayagunaan media pembelajaran, melibatkan siswa dalam berbagai pengalaman belajar, motivasi siswa, rasa percaya diri siswa dan manajemen kelas.

Dari uraian diatas dapat disimpulkan bahwa kinerja guru adalah hasil kerja atau prestasi yang dicapai seorang guru dalam melaksanakan tugasnya sebagai pendidik dan pengajar di suatu instansi pendidikan. Kinerja guru terdiri dari beberapa dimensi, yakni: perencanaan program pengajaran, pelaksanaan kegiatan pembelajaran dan evaluasi hasil pembelajaran serta hubungan interaksi antara guru dan siswa.

\section{Kompetensi Manajerial Kepala Sekolah}

Kompetensi berasal dari bahasa Inggris "competence" yang mempunyai arti kemampuan atau kecakapan. Istilah kompetensi manajerial berasal dari kata manajemen yang berarti mengelola. Menurut Hasibuan (2009) manajemen atau manajerial adalah serangkaian kegiatan ilmu dan seni mengatur proses pemanfaatan sumber daya manusia dan sumber dayasumber daya lainnya secara efektif dan efisien untuk suatu tujuan tertentu. 
Pemerintah menjadikan kompetensi manajerial salah satu kompetensi yang harus dimiliki oleh kepala sekolah. Peraturan Menteri Pendidikan Nasional Nomor 13 tahun 2007 tentang standar kepala sekolah/ madrasah, ditegaskan bahwa ada lima kompetensi dasar yang harus dimiliki oleh seorang kepala sekolah, salah satunya kompetensi manajerial. Di dalam Permendiknas, kompetensi manajerial kepala sekolah adalah kemampuan mengendalikan seluruh sumber daya dalam satuan pendidikan untuk mencapai visi, dan misi, serta tujuan satuan pendidikan.

Yukl (2013: 407), Winterton et al. (2002), dan Katz \& Porter (dalam Dahlan, 2017) mendefinisikan kompetensi manajerial kepala sekolah dalam rangka pelaksanaan tugas manajerial paling tidak diperlukan tiga macam bidang keterampilan, yakni: Keterampilan konseptual, yaitu kemampuan untuk mengkoordinasikan dan mengintegrasikan semua kepentingan dan aktivitas organisasi, yang kedua keterampilan manusiawi, yaitu keterampilan bekerjasama dengan orang lain, memahami, memotivasi setiap individu atau kelompok, dan yang terakhir keterampilan teknik, yaitu kemampuan manusia untuk menggunakan prosedur, teknis, dan pengetahuan mengenai bidang khusus.

Berdasarkan definisi di atas, maka dapat disimpulkan bahwa kompetensi manajerial kepala sekolah adalah kemampuan dan keterampilan yang harus dimiliki oleh seorang kepala sekolah dalam mengelola, memanfaatkan dan memberdayakan segala sumber daya yang terdapat di dalam organisasi pendidikan demi mencapai visi dan misi. Keterampilan manajerial tersebut terdiri dari tiga dimensi keterampilan, yaitu: konseptual (conceptual skill), manusiawi (human skill) dan teknis (technical skill).

\section{Iklim Sekolah}

Setiap sekolah memiliki iklim yang membedakannya dari sekolah lain dan mempengaruhi perilaku dan perasaan guru dan siswa (Sihotang, 2018). Litwin dan Stringer (dalam Gunbayi, 2007: 70) menjelaskan bahwa iklim sekolah didefinisikan sebagai hasil dari persepsi subjektif terhadap sistem formal, gaya informal kepala sekolah, dan faktor lingkungan penting lainnya yang memepengaruhi sikap, kepercayaan, nilai dan motivasi individu yang berada pada sekolah tersebut. Hoy dan Miskel (2008) mengatakan iklim sekolah adalah seperangkat sifat terukur dari lingkungan sekolah, berdasarkan persepsi kolektif masyarakat yang tinggal dan bekerja di lingkungan dan terbukti mempengaruhi tingkah laku mereka dalam bekerja.

Collquitt (2015: 51) membagi 2 dimensi iklim di sebuah organisasi yang dapat memengaruhi kinerja. Pertama adalah dimensi citizenship behavior dan yang kedua adalah counter-productive behavior. Dimensi citizenship behavior terdiri dari 2 bagian yaitu; interpersonal (helping, courtesy dan sportsmanship) dan organizational (voice, civic virtue dan boosterism). Dimensi counter-productive behavior terdiri dari 4 bagian, yaitu; property deviance (sabotage dan theft), production deviance (wasting resources dan substance abuse), political deviance (gossiping dan incivility) dan personal aggression (harassment dan abuse). 
Cohen et.al. (dalam Pinkus, 2009:14), menjabarkan pengukuran iklim sekolah ke dalam 10 dimensi, yang dikelompokkan ke dalam empat kategori, yaitu; safety, teaching and learning, interpersonal relationships, dan institutional environment. Pada kategori safety meliputi rules, physical safety dan social emotional security. Pada kategori teaching and learning meliputi support for learning dan social and civic learning. Pada kategori interpersonal relationships meliputi respect for diversity, social support adults' dan social support students'. Pada kategori institutional environment meliputi school connectedness/ engagement dan physical surroundings.

Berdasarkan pembahasan di atas, dapat disintesiskan bahwa iklim sekolah adalah keseluruhan pandangan, pendapat dan pengalaman yang dirasakan atau dialami oleh setiap guru ketika bekerja terhadap situasi dan keadaan sekolah baik yang bersifat tangible ataupun intangible. Untuk mengukur variabel iklim sekolah, disimpulkan dari beberapa pendapat ahli yang kemudian terbagi menjadi beberapa dimensi. Adapun dimensi-dimensi di dalam iklim sekolah yang akan diukur, diantaranya: hubungan antara pribadi (interpersonal relationship), keselamatan (safety) \& lingkungan fisik (institutional environment), dan komitmen organisasi (committed).

\section{METODOLOGI PENELITIAN}

Penelitian ini menggunakan pendekatan kuantitatif dengan metode survey dengan teknik korelasional. Hubungan antara variabel bebas kompetensi manajerial kepala sekolah (X1), iklim kerja (X2) dengan variabel terikat kinerja guru (Y). Konstelasi penelitian dapat dilihat gambar dibawah ini.

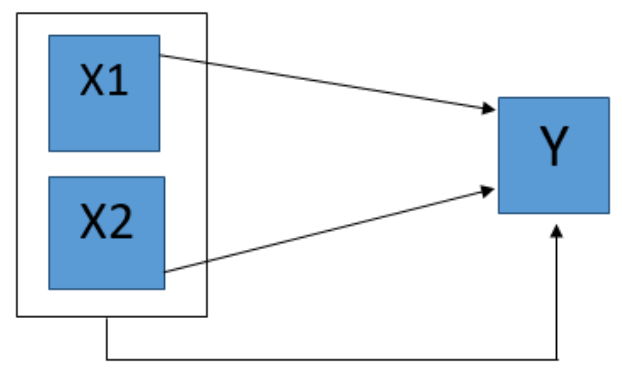

\section{Gambar 1. Konstelasi Penelitian}

\section{Populasi dan Sampel}

Populasi penelitian berjumlah 150 guru yang tersebar di 8 sekolah dasar swasta di kecamatan Penjaringan Jakarta Utara. Desain pengambilan sampel dalam penelitian ini adalah sampel probabilitas (probability sampling) dengan teknik sampel random sederhana. Dalam menentukan ukuran sampel dari tiap sekolah digunakan rumus Krejie \& Morgan, sehingga jumlah sampel dalam penelitian sebanyak 108 guru.

\section{Teknik Pengumpulan Data}

Teknik yang digunakan untuk mengumpulkan data adalah kuesioner variabel bebas kompetensi manajerial kepala sekolah (X1), iklim sekolah (X2) dan variabel terikat kinerja guru (Y). 


\section{Variabel Penelitian}

\section{Kinerja Guru}

Secara konseptual kinerja guru adalah adalah hasil kerja atau prestasi yang dicapai seorang guru dalam melaksanakan tugasnya sebagai pendidik dan pengajar di suatu instansi pendidikan.

Secara operasional kinerja guru adalah penilaian terhadap kemampuan guru dalam menjalankan tugasnya sebagai pendidik di sekolah. Adapun dimensi dan indikator yang digunakan untuk mengukur kinerja guru, yakni: Perencanaan pembelajaran, pelaksanaan pembelajaran terdiri dari tiga indikator (pengelolaan kelas, penguasaan materi pelajaran dan kemampuan menggunakan strategi dan media belajar), penilaian pembelajaran terdiri dari tiga indikator (kognitif, afektif dan psikomotorik) dan dimensi yang terakhir adalah keterampilan interpesonal atau interpersonal skill terdiri dari dua indikator (komunikasi dan motivasi).

Tabel 1. Kisi-kisi Instrumen Kinerja Guru

\begin{tabular}{lcc}
\hline \multicolumn{1}{c}{ Indikator } & Nomor & Jumlah \\
\hline $\begin{array}{l}\text { Membuat Rencana Pelaksanaan Pembelajaran } \\
\text { (RPP) }\end{array}$ & $1,10,19,23$ & 4 \\
Pengelolaan Kelas & $2,11,20,24$ & 4 \\
Penguasaan Bahan Belajar (Materi Pelajaran) & $3,12,21,4$ & 4 \\
Kemampuan Menggunakan Media dan Strategi & 13,5 & 2 \\
Evaluasi Pembelajaran dalam aspek kognitif & 22 & 1 \\
Evaluasi Pembelajaran dalam aspek afektif & $14,6,15$ & 3 \\
$\begin{array}{l}\text { Evaluasi Pembelajaran dalam aspek } \\
\text { psikomotorik }\end{array}$ & 7,16 & 2 \\
Komunikasi & 8,17 & 2 \\
Motivasi & 9,18 & 2 \\
\hline \multicolumn{1}{c}{ Total } & 24 \\
\hline
\end{tabular}

\section{Kompetensi Manajerial Kepala Sekolah}

Secara konseptual kompetensi manajerial kepala sekolah adalah kemampuan dan keterampilan yang harus dimiliki oleh seorang kepala sekolah dalam mengelola, memanfaatkan dan memberdayakan segala sumber daya yang terdapat di dalam organisasi pendidikan demi mencapai visi dan misi.

Secara operasional kompetensi manajerial adalah penilaian atau data yang diperoleh dari 3 dimensi dan 7 indikator, yakni: Dimensi keterampilan konseptual terdiri dari tiga indikator (kemampuan merencanakan program sekolah, kemampuan mengembangkan organisasi sekolah, dan kemampuan menganalisis SWOT). Dimensi kedua ialah keterampilan teknis yang terdiri dari dua indikator (kemampuan mengelola dan memberdayakan guru dan tendik dan kemampuan kepala sekolah dalam mengelola dan mengoperasikan sarana dan prasarana). Dimensi yang ketiga ialah keterampilan manusiawi yang terdiri dari dua indikator (kemampuan menciptakan budaya dan iklim sekolah yang kondusif serta inovatif dan kemampuan untuk menjadi 'role model' bagi bawahannya). 
Tabel 2. Kisi-kisi Instrumen Kompetensi Manajerial Kepsek

\begin{tabular}{lcc}
\hline \multicolumn{1}{c}{ Indikator } & Nomor & Jumlah \\
\hline Mampu Merencanakan Program Sekolah & $1,9,19,2$ & 4 \\
Mampu Mengembangkan Organisasi Sekolah & $10,20,3,11$ & 4 \\
$\begin{array}{l}\text { Mampu Mengenali Kesempatan dan } \\
\text { Persoalan Sosial (SWOT) }\end{array}$ & $21,4,12,22$ & 4 \\
$\begin{array}{l}\text { Mampu mengelola dan memberdayakan Guru } \\
\text { dan Tendik (tenaga pendidikan) dengan }\end{array}$ & $5,13,23$ & 3 \\
$\begin{array}{l}\text { Efektif } \\
\text { Mampu Mengelola dan Mengoperasikan }\end{array}$ & 14,15 & 2 \\
$\begin{array}{l}\text { Sarpras } \\
\text { Menciptakan Budaya dan Iklim Sekolah yang }\end{array}$ & 6,16 & 2 \\
$\begin{array}{l}\text { Kondusif dan Inovatif } \\
\text { Mampu Menjadi 'Role Model' Bagi Para }\end{array}$ & $7,17,8,18$ & 4 \\
Guru-Guru & & 23 \\
\hline \multicolumn{1}{c}{ Total } \\
\hline
\end{tabular}

\section{Iklim Sekolah}

Secara konseptual iklim sekolah adalah keseluruhan pandangan, pendapat dan pengalaman yang dirasakan atau dialami oleh setiap guru ketika bekerja terhadap situasi dan keadaan sekolah baik yang bersifat tangible ataupun intangible.

Secara operasional pengertian iklim sekolah adalah penilaian yang diukur dari beberapa dimensi dan indikator. Dimensi yang pertama adalah hubungan antara pribadi (interpersonal relationship) terdiri dari empat indikator (hubungan antar pribadi, kesopanan, kerjasama, dan komunikasi). Dimensi yang kedua adalah keselamatan (safety) \& lingkungan fisik (institutional environment) yang terdiri dari satu indikator (lingkungan fisik sekolah dan keselamatan). Dimensi yang terakhir adalah komitment organisasi (committed) yang memiliki satu indikator (disiplin dan komitmen).

Tabel 3. Kisi-kisi Instrumen Iklim Sekolah

\begin{tabular}{lcc}
\hline \multicolumn{1}{c}{ Indikator } & Nomor & Jumlah \\
\hline Hubungan Antar Pribadi & $1,11,21,2$ & 4 \\
Sopan Santun dan Saling Menghargai & $12,22,3,13,23$ & 5 \\
Kerjasama & $4,14,24,5$ & 4 \\
Komunikasi & $15,25,6,16$ & 4 \\
Lingkungan Fisik Sekolah dan & $26,7,17,8$ & 4 \\
Keselamatan & & \\
Disiplin dan Komitmen Diri & $18,9,19,10,20$ & 5 \\
\hline
\end{tabular}

\section{Teknik Analisa Data}

Di dalam teknik analisa data terdapat beberapa tahapan, antara lain mendeskripsikan data statistik, uji asumsi klasik dan pengujian hipotesis. Uji asumsi klasik dilakukan sebagai syarat untuk uji hipotesis korelasi dan regresi. Uji tersebut meliputi uji normalitas dan uji linearitas. Uji normalitas menggunakan rumus kolmogrov-smirnov dan linearitas dengan uji linearitas regresi. Uji hipotesis terdiri dari 
korelasi Pearson Product Moment untuk menginterprestasi koefisien korelasi. Berikut adalah pedoman interprestasi koefisien korelasi.

Tabel 4. Interpretasi Koefisien Korelasi

\begin{tabular}{ll}
\hline Interval Koefisien & \multicolumn{1}{c}{ Tingkat Hubungan } \\
\hline $0.000-0.199$ & Tingkat Hubungan Sangat Rendah \\
$0.200-0.399$ & Tingkat Hubungan Rendah \\
$0.400-0.599$ & Tingkat Hubungan Cukup Kuat \\
$0.600-0.799$ & Tingkat Hubungan Kuat \\
$0.800-1.00$ & Tingkat Hubungan Sangat Kuat \\
\hline
\end{tabular}

Setelah itu dilakukan uji regresi untuk mencari ada tidaknya korelasi antara variabel bebas dengan variabel terikat. Secara luas, analisis regresi yang dimaksud adalah sebagai suatu analisis tentang kebergantungan suatu variabel terhadap variabel lain (Neolaka, 2014). Analisis regresi terdiri dari beberapa pembahasan, antara lain: determinasi varians, uji signifikansi korelasi sederhana melalui uji t, persamaan garis regresi linier dengan persamaan $\hat{\mathrm{Y}}=\mathrm{a}+\mathrm{bx}_{1}$. Terakhir adalah melakukan uji regresi dan korelasi berganda (multiple correlation) digunakan untuk melihat kekuatan pengaruh atau hubungan dua variabel bebas $(\mathrm{X} 1, \mathrm{X} 2)$ atau lebih secara bersama-sama dengan satu variabel terikat (Y).

5. Hipotesis Statistik

1. Ho: $\rho y_{1}=0$

Ha: $\rho y_{1} \neq 0$

2. Ho: $\rho y_{2}=0$

Ha: $\rho y_{2} \neq 0$

3. Ho: $\rho y_{12}=0$

Ha: $\rho y_{12} \neq 0$

6. Hasil Penelitian dan Pembahasan

1. Deskripsi Hasil penelitian Kinerja Guru (Y)

Berdasarkan rekapitulasi jawaban 108 guru terhadap variabel kinerja guru diperoleh skor minimum sebesar 3.04 dan maksimum sebesar 3.71.

\begin{tabular}{|c|c|c|}
\hline \multirow[t]{2}{*}{$\mathrm{N}$} & Valid & 108 \\
\hline & Missing & 0 \\
\hline \multicolumn{2}{|c|}{ Mean } & 3.3349 \\
\hline \multicolumn{2}{|c|}{ Std. Error of Mean } & .01505 \\
\hline \multicolumn{2}{|c|}{ Median } & 3.3333 \\
\hline \multicolumn{2}{|c|}{ Mode } & $3.29^{\mathrm{a}}$ \\
\hline \multicolumn{2}{|c|}{ Std. Deviation } & .15641 \\
\hline \multicolumn{2}{|c|}{ Variance } & .024 \\
\hline \multicolumn{2}{|c|}{ Range } & .67 \\
\hline \multicolumn{2}{|c|}{ Minimum } & 3.04 \\
\hline \multicolumn{2}{|c|}{ Maximum } & 3.71 \\
\hline \multicolumn{2}{|c|}{ Sum } & 360.17 \\
\hline \multirow{2}{*}{$\begin{array}{l}\text { Percenti } \\
\text { les }\end{array}$} & 25 & 3.2083 \\
\hline & 50 & 3.3333 \\
\hline
\end{tabular}




\section{$75 \quad 3.4167$}

Data kinerja guru memiliki modus (mode) sebesar 3.29, rata-rata (mean) sebesar 3.33 dan nilai tengah (median) sebesar 3.33, artinya sebagian besar guru memilih setuju atas pernyataan-pernyataan didalam kinerja guru. Jumlah data sebesar 360 dan standar deviasi 0.156 .

Tabel 6. Pengolahan Distribusi Frekuensi Kinerja Guru

\begin{tabular}{cccccc}
\hline KELAS & KELAS & \multicolumn{2}{c}{ BATAS KELAS } & \multicolumn{2}{c}{ FREKUENSI } \\
\cline { 3 - 6 } & INTERVAL & BAWAH & ATAS & ABSOLUT & RELATIF \\
$\mathbf{1}$ & $3.04-3.11$ & 3.035 & 3.115 & 11 & $10 \%$ \\
$\mathbf{2}$ & $3.12-3.19$ & 3.115 & 3.195 & 7 & $7 \%$ \\
$\mathbf{3}$ & $3.20-3.27$ & 3.195 & 3.275 & 19 & $18 \%$ \\
$\mathbf{4}$ & $3.28-3.35$ & 3.275 & 3.355 & 24 & $22 \%$ \\
$\mathbf{5}$ & $3.36-3.43$ & 3.355 & 3.435 & 22 & $20 \%$ \\
$\mathbf{6}$ & $3.44-3.51$ & 3.435 & 3.515 & 10 & $9 \%$ \\
$\mathbf{7}$ & $3.52-3.59$ & 3.515 & 3.595 & 9 & $8 \%$ \\
$\mathbf{8}$ & $3.60-3.67$ & 3.595 & 3.675 & 5 & $5 \%$ \\
$\mathbf{9}$ & $3.68-3.75$ & 3.675 & 3.755 & 1 & $1 \%$ \\
\hline & Total & & & 108 & $100 \%$ \\
\hline
\end{tabular}

2. Deskripsi Hasil Penelitian Kompetensi Manajerial Kepala Sekolah (X1)

Berdasarkan tabel 7 dapat dilihat bahwa data tersebut memiliki rata-rata (mean) sebesar 3.37, nilai tengah (median) sebesar 3.34 dan modus (mode) sebesar 3.35. Adapun nilai minimum sebesar 3.04, nilai maksimum sebesar 3.74, jumlah data sebesar 364 dan standar deviasi 0.181 .

Tabel 7. Deskripsi Statistik Kompetensi Manajerial Kepala Sekolah

\begin{tabular}{|c|c|c|}
\hline \multirow[t]{2}{*}{$\mathrm{N}$} & Valid & 108 \\
\hline & Missing & 0 \\
\hline \multicolumn{2}{|l|}{ Mean } & 3.3724 \\
\hline \multicolumn{2}{|c|}{ Std. Error of Mean } & .01748 \\
\hline \multicolumn{2}{|c|}{ Median } & 3.3478 \\
\hline \multicolumn{2}{|l|}{ Mode } & 3.35 \\
\hline \multicolumn{2}{|c|}{ Std. Deviation } & .18169 \\
\hline \multicolumn{2}{|c|}{ Variance } & .033 \\
\hline \multicolumn{2}{|l|}{ Range } & .70 \\
\hline \multicolumn{2}{|l|}{ Minimum } & 3.04 \\
\hline \multicolumn{2}{|l|}{ Maximum } & 3.74 \\
\hline \multicolumn{2}{|l|}{ Sum } & 364.22 \\
\hline \multirow[t]{3}{*}{ Percentiles } & 25 & 3.2609 \\
\hline & 50 & 3.3478 \\
\hline & 75 & 3.4783 \\
\hline
\end{tabular}


Setelah itu dilakukan perhitungan distribusi frekuensi terhadap skor jawaban variabel kompetensi manajerial kepala sekolah dapat di lihat pada Tabel di bawah ini.

Tabel 8. Pengolahan Distribusi Frekuensi Kompetensi Manajerial Kepala Sekolah

\begin{tabular}{cccccc}
\hline KELAS & KELAS & \multicolumn{2}{c}{ BATAS KELAS } & \multicolumn{2}{c}{ FREKUENSI } \\
\cline { 3 - 6 } & INTERVAL & BAWAH & ATAS & ABSOLUT & RELATIF \\
$\mathbf{1}$ & $3.04-3.11$ & 3.035 & 3.115 & 9 & 8 \\
$\mathbf{2}$ & $3.12-3.19$ & 3.115 & 3.195 & 11 & 10 \\
$\mathbf{3}$ & $3.20-3.27$ & 3.195 & 3.275 & 13 & 12 \\
$\mathbf{4}$ & $3.28-3.35$ & 3.275 & 3.355 & 22 & 20 \\
$\mathbf{5}$ & $3.36-3.43$ & 3.355 & 3.435 & 20 & 19 \\
$\mathbf{6}$ & $3.44-3.51$ & 3.435 & 3.515 & 10 & 9 \\
$\mathbf{7}$ & $3.52-3.59$ & 3.515 & 3.595 & 7 & 7 \\
$\mathbf{8}$ & $3.60-3.67$ & 3.595 & 3.675 & 9 & 8 \\
$\mathbf{9}$ & $3.68-3.75$ & 3.675 & 3.755 & 7 & 7 \\
\hline & Total & & & 108 & $100 \%$ \\
\hline
\end{tabular}

3. Deskripsi Hasil penelitian Iklim Sekolah (X2)

Berdasarkan Tabel $4.15 \mathrm{di}$ atas dapat dilihat bahwa data iklim sekolah di kecamatan Penjaringan memiliki rata-rata (mean) sebesar 3.42, nilai tengah (median) sebesar 3.42, modus (mode) sebesar 3.43. Nilai minimum sebesar 3.10, nilai maksimum sebesar 3.76, jumlah data sebesar 370 dan standar deviasi 0.169 .

\begin{tabular}{lrr}
\multicolumn{2}{c}{ Tabel 9. Deskripsi Statistik Iklim Sekolah } \\
\hline N & Valid & 108 \\
& Missing & 0 \\
Mean & & 3.4290 \\
Std. Error of Mean & .01634 \\
Median & 3.4286 \\
Mode & 3.43 \\
Std. Deviation & .16983 \\
Variance & .029 \\
Range & & .67 \\
Minimum & & 3.10 \\
Maximum & & 3.76 \\
Sum & 25 & 370.33 \\
Percentile & 25 & 3.2857 \\
s & 50 & 3.4286 \\
& 75 & 3.5714 \\
\hline
\end{tabular}

Berdasarkan Tabel 4.15 di atas dapat dilihat bahwa data iklim sekolah di kecamatan Penjaringan memiliki rata-rata (mean) sebesar 3.42, nilai tengah (median) sebesar 3.42, modus (mode) sebesar 3.43. Nilai minimum sebesar 3.10, nilai maksimum sebesar 3.76, jumlah data sebesar 370 dan standar deviasi 0.169 . 
Tabel 10. Pengolahan Distribusi Frekuensi Iklim Sekolah

\begin{tabular}{cccccc}
\hline KELAS & KELAS & \multicolumn{2}{c}{ BATAS KELAS } & \multicolumn{2}{c}{ FREKUENSI } \\
\cline { 3 - 6 } & INTERVAL & BAWAH & ATAS & ABSOLUT & RELATIF \\
$\mathbf{1}$ & $3.10-3.17$ & 3.095 & 3.175 & 7 & 6 \\
$\mathbf{2}$ & $3.18-3.25$ & 3.175 & 3.255 & 13 & 12 \\
$\mathbf{3}$ & $3.26-3.33$ & 3.255 & 3.335 & 18 & 17 \\
$\mathbf{4}$ & $3.34-3.41$ & 3.335 & 3.415 & 9 & 8 \\
$\mathbf{5}$ & $3.42-3.49$ & 3.415 & 3.495 & 23 & 22 \\
$\mathbf{6}$ & $3.50-3.57$ & 3.495 & 3.575 & 17 & 16 \\
$\mathbf{7}$ & $3.58-3.65$ & 3.575 & 3.655 & 7 & 6 \\
$\mathbf{8}$ & $3.66-3.73$ & 3.655 & 3.735 & 12 & 11 \\
$\mathbf{9}$ & $3.74-3.81$ & 3.735 & 3.815 & 2 & 2 \\
\hline & Total & & & 108 & $100 \%$ \\
\hline
\end{tabular}

\section{Uji Persyaratan Analisis}

Uji normalitas menggunakan rumus Kolmogorov-Smirnov Test. Nilai signifikansi yang diperoleh dari ketiga variabel sebesar 0.200. Berarti data sampel bersifat normal karena lebih besar dari 0.05

Selanjutnya menguji linearitas pada taraf signifikasi 0.05 . Hasil uji linearitas antara X1 dan Y diperoleh nilai Sig. sebesar 0,000. Kemudian variabel X2 dengan Y diperoleh nilai Sig. sebesar 0,000. Maka uji kelinearan telah terpenuhi.

\section{Uji Hipotesis}

1. Hubungan Kompetensi Manajerial Kepala Sekolah dan Kinerja Guru

Hasil pengujian hipotesis pertama adalah untuk melihat kuatnya hubungan variabel $\mathrm{X} 1$ terhadap $\mathrm{Y}$. Hasilnya dapat dilihat pada Tabel di bawah ini.

Tabel 11. Korelasi X1 dengan $Y$

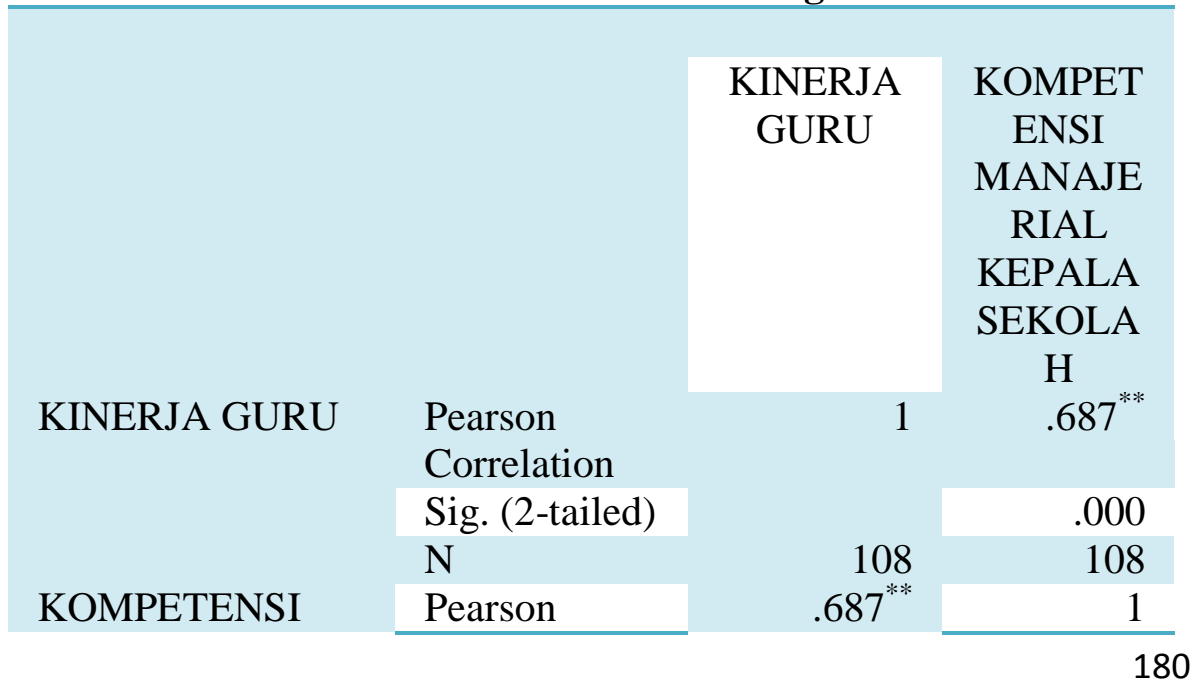




\begin{tabular}{|c|c|c|c|}
\hline MANAJERIAL & Correlation & & \\
\hline KEPALA & Sig. (2-tailed) & .000 & \\
\hline SEKOLAH & $\mathrm{N}$ & 108 & 108 \\
\hline
\end{tabular}

Diperoleh koefisien korelasi sebesar 0.687. Dapat disimpulkan bahwa hubungan kompetensi manajerial kepala sekolah dengan kinerja guru bernilai positif dan korelasi bersifat kuat.

Tabel 12. Persamaan Regresi X1 dengan Y

\begin{tabular}{|c|c|c|c|c|c|}
\hline \multirow[t]{2}{*}{ Model } & \multicolumn{2}{|c|}{$\begin{array}{l}\text { Unstandardi } \\
\text { zed } \\
\text { Coefficients }\end{array}$} & $\begin{array}{l}\text { Standa } \\
\text { rdized } \\
\text { Coeffi }\end{array}$ & \multirow[t]{2}{*}{$\mathrm{t}$} & \multirow[t]{2}{*}{ Sig. } \\
\hline & $\mathrm{B}$ & $\begin{array}{l}\text { Std. } \\
\text { Error }\end{array}$ & Beta & & \\
\hline 1 (Constant) & & 32.144 & 4.923 & & 6.530 \\
\hline $\begin{array}{l}\text { KOMPETEN } \\
\text { SI } \\
\text { MANAJERIA } \\
\text { L KEPSEK }\end{array}$ & & .617 & .063 & .687 & 9.743 \\
\hline a. Dependent Var & iabl & KINERJ & GURU & & \\
\hline
\end{tabular}

Kompetensi manajerial kepala sekolah dengan kinerja guru menghasilkan koefisin arah regresi 0.617 dan konstanta 32.144. Berarti arah hubungan $\mathrm{X} 1$ dengan $\mathrm{Y}$ positif dan persamaan regresi sederhana $\hat{Y}=32.144+0.617 \mathrm{X}_{1}$. Hal ini berarti semakin baik kompetensi manajerial kepala sekolah, maka kinerja guru akan baik pula. Uji t dilakukan dengan membandingan nilai $\mathrm{t}$ tabel dengan nilai $\mathrm{t}$ hitung, maka disimpulkan bahwa hipotesis Ho ditolak dan $\mathrm{Ha}$ diterima yang berarti terdapat hubungan yang positif dan signifikan antara kompetensi manajerial kepala sekolah dengan kinerja guru.

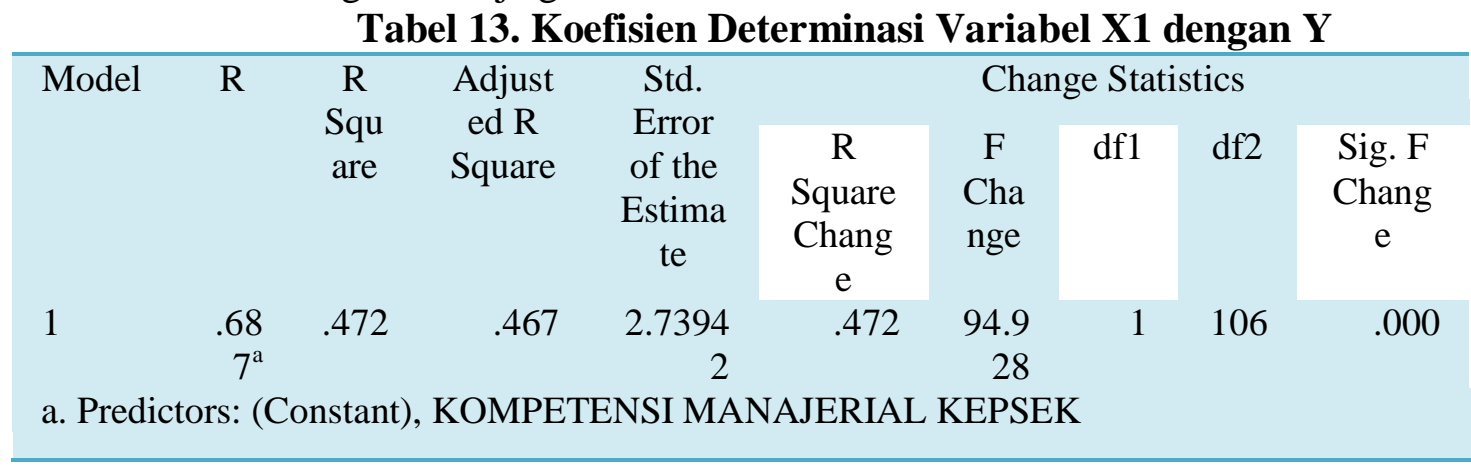

Berdasarkan tabel di atas diperoleh koefisien determinasi sebesar 0.472 , berarti sebesar $47,2 \%$ terjadi dalam kecenderungan meningkatnya kinerja guru dapat dipengaruhi oleh baiknya kompetensi manajerial kepala sekolah dan sisanya 52,8\% dipengaruhi oleh faktor lain yang tidak diteliti pada penelitian ini. 
2. Hubungan Iklim Sekolah dengan Kinerja Guru

Pengujian hipotesis pertama dilakukan dengan melihat kuatnya hubungan variabel X2 terhadap Y. Hasilnya dapat dilihat pada Tabel di bawah ini.

Tabel 14. Korelasi X2 dengan Y

\begin{tabular}{|c|c|c|c|}
\hline \multirow{3}{*}{$\begin{array}{l}\text { KINERJA } \\
\text { GURU }\end{array}$} & & \multirow{2}{*}{$\begin{array}{l}\text { KINERJA } \\
\text { GURU } \\
\end{array}$} & \multirow{2}{*}{$\begin{array}{c}\text { IKLIM } \\
\text { SEKOLAH } \\
.463^{* *}\end{array}$} \\
\hline & Pearson & & \\
\hline & Correlation & & \\
\hline \multirow{6}{*}{$\begin{array}{l}\text { IKLIM } \\
\text { SEKOLAH }\end{array}$} & Sig. (2-tailed) & \multirow[b]{2}{*}{108} & .000 \\
\hline & $\mathrm{N}$ & & 108 \\
\hline & Pearson & $.463^{* *}$ & 1 \\
\hline & Correlation & & \\
\hline & Sig. (2-tailed) & .000 & \\
\hline & $\mathrm{N}$ & 108 & 108 \\
\hline
\end{tabular}

Diperoleh koefisien korelasi sebesar 0.463. Dapat disimpulkan bahwa iklim sekolah dengan kinerja guru bernilai positif dan berkorelasi cukup kuat.

Tabel 15. Persamaan Regresi X2 dengan Y

\begin{tabular}{|c|c|c|c|c|c|c|}
\hline \multirow{2}{*}{\multicolumn{2}{|c|}{ Model }} & \multicolumn{2}{|c|}{$\begin{array}{l}\text { Unstandardized } \\
\text { Coefficients }\end{array}$} & $\begin{array}{l}\text { Standardi } \\
\text { zed }\end{array}$ & \multirow[t]{2}{*}{$\mathrm{t}$} & \multirow[t]{2}{*}{ Sig. } \\
\hline & & B & $\begin{array}{l}\text { Std. } \\
\text { Error }\end{array}$ & Beta & & \\
\hline \multirow[t]{2}{*}{1} & (Constant) & 44.960 & 6.534 & \multirow[b]{2}{*}{.463} & 6.881 & .000 \\
\hline & $\begin{array}{l}\text { IKLIM } \\
\text { SEKOLAH }\end{array}$ & .487 & .091 & & 5.375 & .000 \\
\hline \multicolumn{6}{|c|}{ a. Dependent Variable: KINERJA GURU } & \\
\hline
\end{tabular}

Iklim sekolah dengan kinerja guru menghasilkan koefisien arah regresi 0.487 dan konstanta 44.960. Berarti arah hubungan X2 dengan $\mathrm{Y}$ positif dan persamaan regresi sederhana $\hat{\mathrm{Y}}=44.960+$ $0.487 \mathrm{X}_{2}$. Hal ini berarti semakin baik iklim sekolah, maka kinerja guru akan baik pula. Uji $\mathrm{t}$ dilakukan dengan membandingan nilai $\mathrm{t}$ tabel dengan nilai t hitung, maka disimpulkan bahwa hipotesis Ho ditolak dan Ha diterima yang berarti terdapat hubungan yang positif dan signifikan antara iklim sekolah dengan kinerja guru.

Tabel 16. Koefisien Determinasi Variabel X2 dengan Y

\begin{tabular}{|c|c|c|c|c|c|c|c|c|c|}
\hline \multirow[t]{2}{*}{ Model } & \multirow[t]{2}{*}{$\mathrm{R}$} & \multirow{2}{*}{$\begin{array}{c}\mathrm{R} \\
\text { Squa } \\
\text { re }\end{array}$} & \multirow{2}{*}{$\begin{array}{l}\text { Adjuste } \\
\text { d R } \\
\text { Square }\end{array}$} & & \multicolumn{5}{|c|}{ Change Statistics } \\
\hline & & & & $\begin{array}{l}\text { Error of } \\
\text { the } \\
\text { Estimat } \\
\text { e }\end{array}$ & $\begin{array}{c}\text { R } \\
\text { Square } \\
\text { Change }\end{array}$ & $\begin{array}{c}\text { F } \\
\text { Chan } \\
\text { ge }\end{array}$ & df1 & $\mathrm{df} 2$ & $\begin{array}{l}\text { Sig. F } \\
\text { Change }\end{array}$ \\
\hline 1 & $\begin{array}{r}.4 \\
63 \\
\mathrm{a}\end{array}$ & .214 & .207 & 3.34341 & .214 & $\begin{array}{r}28.89 \\
0\end{array}$ & 1 & 106 & .000 \\
\hline
\end{tabular}


Berdasarkan tabel di atas diperoleh koefisien determinasi sebesar 0.214 , berarti sebesar $21,4 \%$ terjadi dalam kecenderungan meningkatnya kinerja guru dapat dipengaruhi oleh baiknya suasana iklim sekolah.

3. Hubungan Kompetensi Manajerial Kepala Sekolah dan Iklim Sekolah dengan Kinerja Guru

Hubungan antara variabel X1 dan X2 secara bersama-sama dengan variabel Y ditunjukkan oleh koefisien korelasi ganda yang dapat dilihat pada tabel berikut ini.

Tabel. 17 Korelasi Ganda dan Koefisien Determinasi

\begin{tabular}{|c|c|c|c|c|c|c|c|c|c|}
\hline \multirow[t]{2}{*}{ Model } & \multirow[t]{2}{*}{$\mathrm{R}$} & $\mathrm{R}$ & Adjusted & Std. & \multicolumn{5}{|c|}{ Change Statistics } \\
\hline & & $\begin{array}{l}\text { Squ } \\
\text { are }\end{array}$ & $\begin{array}{c}\text { R } \\
\text { Square }\end{array}$ & $\begin{array}{c}\text { Error of } \\
\text { the } \\
\text { Estimate }\end{array}$ & $\begin{array}{c}\text { R } \\
\text { Square } \\
\text { Change }\end{array}$ & $\begin{array}{c}\text { F } \\
\text { Chan } \\
\text { ge }\end{array}$ & df1 & df 2 & $\begin{array}{l}\text { Sig. F } \\
\text { Change }\end{array}$ \\
\hline 1 & $\begin{array}{r}.70 \\
3^{\mathrm{a}}\end{array}$ & $\begin{array}{r}.49 \\
4\end{array}$ & .484 & 2.69606 & .494 & $\begin{array}{r}51.22 \\
2\end{array}$ & 2 & 105 & .000 \\
\hline
\end{tabular}

Diperoleh koefisien korelasi ganda sebesar 0.703 dan koefisien determinasi sebesar 0.494 . Hal ini berarti korelasi ganda bernilai positif dan hubungan ketiga variabel bersifat kuat, serta $49,4 \%$ variasi kinerja guru dipengaruhi oleh kompetensi manajerial kepala sekolah dan iklim sekolah secara bersama-sama, dan sisanya $50,6 \%$ dipengaruhi oleh faktor lain.

Tabel 18. ANOVA Pengujian Signifikansi Korelasi Ganda

\begin{tabular}{|c|c|c|c|c|c|c|c|}
\hline \multicolumn{8}{|c|}{ ANOVA $^{\mathrm{a}}$} \\
\hline \multicolumn{2}{|c|}{ Model } & $\begin{array}{c}\text { Sum of } \\
\text { Squares }\end{array}$ & df & $\begin{array}{c}\text { Mean } \\
\text { Square }\end{array}$ & $\mathrm{F}$ & Sig & \\
\hline \multicolumn{3}{|c|}{1 Regression } & $\begin{array}{r}744 . \\
635\end{array}$ & 2 & $\begin{array}{r}372.3 \\
18\end{array}$ & 51.222 & $.000^{\mathrm{b}}$ \\
\hline \multicolumn{3}{|c|}{ Residual } & $\begin{array}{r}763 . \\
216\end{array}$ & 105 & 7.269 & & \\
\hline \multicolumn{2}{|r|}{ Total } & & $\begin{array}{r}150 \\
7.85 \\
2\end{array}$ & 107 & & & \\
\hline \multicolumn{8}{|c|}{ a. Dependent Variable: KINERJA GURU } \\
\hline \multicolumn{8}{|c|}{$\begin{array}{l}\text { b. Predictors: (Constant), IKLIM SEKOLAH, KOMPETENSI MANAJERIAL } \\
\text { KEPSEK }\end{array}$} \\
\hline
\end{tabular}

Diperoleh nilai $F_{\text {hitung }}$ sebesar 51.222. Derajat bebas (db) 2:105 dan taraf signifikan $\alpha 0.05$ adalah sebesar 3.081. Hal ini menunjukkan bahwa $F_{\text {hitung }}$ (51.222) lebih besar dari $F_{\text {tabel }}$ (3.081). Maka dapat diambil kesimpulan bahwa hipotesis Ho ditolak dan Ha diterima yang berarti terdapat hubungan yang positif dan signifikan antara kompetensi manajerial kepala sekolah dan iklim sekolah secara bersama-sama dengan kinerja guru sekolah dasar swasta di kecamatan Penjaringan. Hubungan antara kompetensi manajerial kepala sekolah dan iklim sekolah secara bersama-sama dengan kinerja guru dapat dilihat dengan persamaan regresi ganda pada tabel di bawah ini. 
Tabel. 19 Persamaan Regresi Ganda X1 dan X2 dengan Y

\begin{tabular}{|c|c|c|c|c|c|c|}
\hline \multirow[t]{2}{*}{ Model } & \multicolumn{2}{|c|}{$\begin{array}{l}\text { Unstandardized } \\
\text { Coefficients }\end{array}$} & \multicolumn{2}{|c|}{$\begin{array}{c}\text { Standardiz } \\
\text { ed } \\
\text { Coefficien } \\
\text { ts }\end{array}$} & \multirow[t]{2}{*}{$\mathrm{t}$} & \multirow[t]{2}{*}{ Sig. } \\
\hline & B & $\begin{array}{l}\text { Std. } \\
\text { Error }\end{array}$ & $\mathrm{Be}$ & & & \\
\hline 1 (Con & & 25.138 & 5.877 & & 4.278 & .000 \\
\hline $\begin{array}{l}\text { KOM } \\
\text { MAN } \\
\text { KEP }\end{array}$ & $\begin{array}{l}\text { NSI } \\
\text { IAL }\end{array}$ & .544 & .071 & .606 & 7.617 & .000 \\
\hline $\begin{array}{l}\text { IKLI } \\
\text { SEK }\end{array}$ & & .176 & .084 & .168 & 2.107 & .038 \\
\hline
\end{tabular}

Kompetensi manajerial kepala sekolah dan iklim sekolah bersamasama dengan kinerja guru menghasilkan koefisien regresi 0.544 dan 0.176 dan konstanta sebesar 25.138. Dengan demikian hubungan antara kompetensi manajerial kepala sekolah dan iklim sekolah bersama-sama dengan kinerja guru memiliki persamaan regresi ganda $\hat{\mathrm{Y}}=25.138+0.544 \mathrm{X}_{1}+0.176 \mathrm{X}_{2}$. Maka kesimpulannya adalah terdapat hubungan antara kompetensi manajerial kepala sekolah dan iklim sekolah secara bersama-sama dengan kinerja guru sekolah dasar swasta di kecamatan Penjaringan.

\section{PEMBAHASAN}

1. Hubungan Kompetensi Manajerial Kepala Sekolah dan Kinerja Guru Berdasarkan hasil perhitungan, diperoleh persamaan regresi untuk hubungan kedua variabel tersebut, yaitu $\hat{Y}=32.144+0.617$ X1. Hasil perhitungan menunjukan koefisien arah regresi sebesar 0.617 dan konstanta 32.144 yang berarti, setiap kenaikan satu skor variabel X1 akan menaikkan skor variabel Y sebesar 0.617 serta bentuk hubungan antara variabel X1 dan Y berdasarkan model regresinya adalah positif. Hal ini berarti tanpa adanya kompetensi manajerial kepala sekolah yang baik, kinerja guru sudah menunjukan angka 32.144 namun tergolong masih rendah. Oleh karena itu kompetensi manajerial kepala sekolah sangat dibutuhkan dalam meningkatkan kinerja guru.

Berdasarkan hasil di atas, maka seorang kepala sekolah sangat di harapkan memiliki kompetensi manajerial, baik dalam kemampuan merencanakan program-program sekolah, mengembangkan organisasi sekolah, menganalisis (SWOT), memberdayakan guru dan tendik, mengelola \& mengoperasikan sarpras, menciptakan budaya dan iklim sekolah yang sehat serta kemampuan untuk menjadi role model bagi bawahannya. Berdasarkan hal tersebut dapat diinterpretasikan bahwa untuk menciptakan 
kinerja guru yang berkualitas sangat ditentukan oleh kompetensi manajerial dari seorang kepala sekolah.

\section{Hubungan Iklim Sekolah dan Kinerja Guru}

Berdasarkan hasil perhitungan, diperoleh persamaan regresi untuk hubungan kedua variabel tersebut, yaitu $\hat{Y}=44.960+0.487$ X2. Dari hasil perhitungan diperoleh koefisien arah regresi sebesar 0.487 dan konstanta 44.960 yang berarti bahwa setiap kenaikan satu skor variabel X2 akan menaikkan skor variabel Y sebesar 0.487 pada konstanta 44.960. Selain itu, bentuk hubungan variabel $\mathrm{X} 2$ dan $\mathrm{Y}$ berdasarkan model regresinya adalah positif.

Berdasarkan hasil penelitian di atas maka masyarakat sekolah perlu untuk menciptakan iklim sekolah yang sehat dengan cara membangun hubungan yang harmonis ditengah-tengah lingkungan kerja, kerjasama dalam melaksanakan kegiatan belajar mengajar, saling menghargai satu dengan yang lain, menciptakan tempat kerja yang nyaman dan aman, berkomitmen untuk mementingkan kepentingan sekolah dibandingkan kepentingan pribadi, mengikuti peraturan yang telah ditetapkan sekolah, dan berkomunikasi dengan rekan sejawat jika mengalami kesulitan. Jika hal tersebut dilakukan, maka akan meningkatkan kinerja guru sekolah dasar swasta di kecamatan Penjaringan.

\section{Hubungan Kompetensi Manajerial Kepala Sekolah dan Iklim Sekolah dengan Kinerja Guru}

Kompetensi manajerial kepala sekolah dan iklim sekolah bersama-sama dengan kinerja guru menghasilkan koefisien regresi 0.544 dan 0.176 dan konstanta sebesar 25.138. Dengan demikian hubungan antara kompetensi manajerial kepala sekolah dan iklim sekolah bersama-sama dengan kinerja guru memiliki persamaan regresi ganda $\hat{Y}=25.138+0.544 \mathrm{X}_{1}+0.176 \mathrm{X}_{2}$. Maka dapat ditarik kesimpulan bahwa hipotesis $\mathrm{H0}$ ditolak dan $\mathrm{Ha}$ diterima yang berarti terdapat hubungan yang positif dan signifikan antara kompetensi manajerial kepala sekolah dan iklim sekolah bersama-sama dengan kinerja guru sekolah dasar swasta di Penjaringan Jakarta Utara.

Hal ini berarti semakin baik kompetensi manajerial kepala sekolah dan iklim sekolah maka akan semakin baik kinerja guru-guru sekolah dasar swasta di kecamatan Penjaringan. Oleh karena itu, sangat penting bagi seorang kepala sekolah untuk terus mengasah \& meningkatkan ilmu manajerialnya ditambah pihak guru yang mampu menghadirkan iklim organisasi yang baik sehingga kinerja guru semakin baik.

\section{E. KESIMPULAN, SARAN, DAN IMPLIKASI}

\section{Kesimpulan}

Berdasarkan hasil penelitian, maka kesimpulan terhadap hipotesis pertama adalah terdapat hubungan yang positif dan signifikan antara kompetensi manajerial kepala sekolah (X1) dengan kinerja guru (Y). Hal ini dilihat dari nilai t hitung (9.743) lebih besar dari t tabel (1.659), selain itu diperoleh koefisien korelasi sebesar 0.687 yang berarti korelasi bernilai positif dan kuat, 
koefisien determinasi sebesar 0.472 , dan persamaan regresi $\hat{Y}=32.144+$ $0.617 X 1$.

Kedua, terdapat hubungan yang positif dan signifikan antara iklim sekolah (X2) dengan kinerja guru (Y). Hal ini ditunjukkan dengan nilai t hitung (5.375) lebih besar dari t tabel (1.659), selain itu diperoleh koefisien korelasi sebesar 0.463 yang berarti korelasi bernilai positif dan cukup kuat, koefisien determinasi sebesar 0.214 , dan persamaan regresi $\hat{Y}=44.960+0.487 X 2$.

Ketiga, terdapat hubungan yang positif dan signifikan antara kompetensi manajerial kepala sekolah (X1) dan iklim sekolah (X2) secara simultan dengan kinerja guru (Y). Hal ini ditunjukkan dengan $\hat{Y}=25.138+0.544 \mathrm{X} 1+$ $0.176 X 2$. Diperoleh koefisien korelasi ganda (r) sebesar 0,703 yang berarti korelasi bernilai positif dan kuat.

\section{Saran}

Dalam meningkatkan kinerja guru, kepala sekolah mempunyai andil yang sangat strategis dalam mencapai tujuan tersebut. Maka hasil penelitian ini disarankan kepada sekolah sebagai informasi bagi kepala sekolah untuk tetap berupaya meningkatkan kompetensi manajerialnya guna meningkatkan kualitas kinerja guru di sekolah yang dipimpinnya.

Selain itu penting bagi pihak sekolah dasar swasta di kecamatan Penjaringan untuk meningkatkan iklim sekolah agar lebih baik. Hasil penelitian ini juga disarankan dapat menjadi tambahan referensi bagi penelitian berikutnya.

\section{Implikasi}

Implikasi yang diperoleh dari penelitian ini adalah menyarankan kepada pengelola ataupun yayasan sekolah dasar swasta untuk tidak hanya memperhatikan aspek pengetahuan, keterampilan dan etika kerja, namun juga harus mulai untuk menguji kompetensi manajerial dari seorang kepala sekolah. Kemudian, iklim sekolah juga menjadi hal yang krusial sehingga mengharuskan seluruh komponen sekolah terutama yang menduduki jabatan top level management \& middle level management untuk memperhatikan iklim sekolah atau keadaan lingkungan sekolah. Dan yang terakhir, penelitian ini juga diharapkan berdampak terhadap pemerintah melauli pengawas sekolah atau dinas pendidikan Jakarta Utara untuk mulai memerhatikan kompetensi manajerial kepala sekolah dan memberikan pelatihan atau seminar terhadap para kepala sekolah dasar yang ada di kecamatan Penjaringan Jakarta Utara.

\section{DAFTAR PUSTAKA}

Barkah, J. (2014). Meningkatkan Kinerja Guru Melalui Kemampuan Manajerial Kepala Sekolah. SOSIO e-KONS, VI (1), 30-40.

Colquitt, J. A., Lepine, J. A., \& Wesson, M. J. (2015). Organizational Behavior. New York: Mc Graw Hill Education.

Dahlan, Iriawan, H., \& Hamdan. (2017). Pengaruh Kompetensi Manajerial Kepala SekolahTerhadap Kompetensi Sosial Guru Di SMA Negeri 11 Makassar. Jurnal Ilmiah Ilmu Administrasi Publik,VII (2), 59-68. 
Dessler, G. (2014). Fundamentals of Human Resource Management. USA: Pearson Education Limited.

English, F. W. (2006). Encyclopedia of Educational Leadership and Administration. California: Sage Publications, Inc.

Ehrhart, M. G. (2014). Organizational Climate and Culture. New York: Routledge.

Gunbayi, I. (2007). School Climate and Teachers' Perceptions on Climate Factors: Research Into Nine Urban High Schools. The Turkish Online Journal of Educational Technology 2002, VI (3), 70-77.

Hasibuan, M. (2009). Manajemen: Dasar, Pengertian dan Masalah. Jakarta: Bumi Aksara.

Hayes, D., Mills, M., Christie, P., \& Lingard, B. (2006). Teachers and Schooling Making A Difference. Australia: Allen \& Unwin.

Hoy, W. K., \& Miskel, C. G. (2008). Educational administration: Theory, research, and practice. New York: McGraw-Hill.

Kamalu, N. S., Selamat, N., \& Samsu, N. Z. (2013). The Impact of Organizational Climate on Teachers' Job Performance. Educational Research e-Journal, I I (1), 71-82.

Neolaka. (2014). Metode Penelitian dan Statistik. Bandung: Remaja Rosdakarya.

Nurdin, D. (2015). Kompetensi Manajerial Kepala Sekolah Dalam Membangun Iklim Sekolah Dan Kepuasaan Guru Di Sekolah Dasar. Jurnal Sekolah Dasar Kajian Teori dan Praktik Pendidikan, XXIV (1), 45-56.

Peraturan Menteri Pendidikan Nasional Republik Indonesia No.13 tahun 2007 tentang Standar Kepala Sekolah/Madrasah. Jakarta: Depdiknas.

Peraturan Menteri Pendidikan Nasional Nomor 35 Tahun 2010. Petunjuk Teknis Pelaksanaan Jabatan Fungsional Guru dan Angka Kreditnya.

Pidarta, M. (2013). Landasan Kependidikan: Stimulus Ilmu Pendidikan Bercorak Indonesia. Jakarta: Rineka Cipta.

Pinkus, L. M. (2009). Moving Beyond AYP: High School Performance Indicators. Washington: Alliance For Excellent Education.

Sihotang, H. (2017). Hubungan Antara Iklim Organisasi dan Motivasi Dengan Kinerja Guru SMA Negeri 60 Jakarta Selatan. Jurnal Manajemen Pendidikan, $V$ (1), 11-26.

(2018). Kepemimpinan Kepala Sekolah, Pendidikan Karakter, Pendidikan Keluarga, Budaya Sekolah, dan Kepemimpinan Guru (studi kualitatif pengelolaan konflik antar siswa di sd st. caroline). Jurnal Manajemen Pendidikan, V (2), 283-298.

Swainston, T. (2008). Effective Teachers in Secondary Schools. New York: Continuum International Publishing Group.

Tampubolon, M. (2012). Perilaku Organisasi. Jakarta: Ghalia Indonesia.

Tirtarahardja, U., \& Sulo, S. L. (2012). Pengantar Pendidikan. Jakarta: Rineka Cipta.

Topping, P. A. (2002). Managerial Leadership. USA: The McGraw-Hill Companies, Inc.

Torrington, D., Earnshaw, J., Marchington, L., \& Ritchie, E. (2004). Tackling Under-Performance in Teachers. London: Routledge Falmer. 
Hubungan Antara Kompetensi Manajerial Kepala Sekolah Dan IKlim Seķlah Dengan Kinerja Guru

Undang-Undang Republik Indonesia Nomor 20 Tahun 2003. Sistem Pendidikan Nasional.

Winterton, J., \& Winterton, R. (2002). Developing Managerial Competence. New York: Routledge.

Yukl, G. (2013). Leadership in Organizations. New Jersey: Pearson Education, Inc.

Koran Jakarta. 27 Februari 2018. Kinerja Guru Belum Efektif, hlm. 1. 